\title{
MENYONTEK SEBAGAI BAGIAN DARI DEKADENSI MORAL BANGSA
}

\author{
Inge Angelia \\ STIKES SyedzaSaintika Padang, Indonesia \\ angeliakhairita01@gmail.com
}

\begin{abstract}
Abstrak
Menyontek saat sekarang ini sudah menjadi hal yang biasa dikalangan peserta didik, dimulai dari bangku sekolah dasar hingga perguruan tinggi. Tujuan dari penulisan artikel ini yaitu untuk mendeskripsikan dan menganalisis perilaku menyontek peserta didik di perguruan tinggi kesehatan. Metode penelitian yang digunakan yaitu metode kuantitatif dengan jumlah sampel 106 orang mahasiswa sekolah tinggi kesehatan di Kota Padang. Hasil penelitian menunjukan $45,3 \%$ responden pernah menyontek. Hal ini tentunya harus menjadi perhatian bagi pemerintah, karena menyontek sebagai bentuk penuruna moral bangsa atau dekadensi moral bangsa. Sehingga disimpulkan bahwa separuh responden berprilaku kurang baik dalam menyontek.
\end{abstract}

\section{A. PENDAHULUAN}

Menyontek merupakan tindakan yang lazim dilakukan oleh pelajar dan mahasiswa. Berdasarkan survei yang telah dilakukan Litbang Media Group pada 19 April 2007 terhadap 480 responden dewasa di enam kota besar di Indonesia, yaitu Makassar, Surabaya, Yogyakarta, Bandung, Jakarta, dan Medan menunjukkan mayoritas anak didik, baik di bangku sekolah dan perguruan tinggi melakukan kecurangan akademik dalam bentuk menyontek. Hampir 70 persen responden yang ditanya apakah pernah menyontek ketika masih sekolah atau kuliah, menjawab pernah (Samiroh, 2015). Hal ini disebabkan oleh kebijakan pemerintah Indonesia yang menggunakan nilai secara kuantitatif sebagai takaran keberhasilan proses belajar, sehingga menjadikan salah satu alasan mengapa praktik-praktik ketidakwajaran masih menghiasi dunia pendidikan hingga saat ini (Sanjaya, 2013).

Menyontek pada saat ujian sepertinya bukan hal yang tabu lagi bagi sebagian kalangan mahasiswa. Berbagai cara dan strategi, mulai dari yang sederhana hingga tercanggih, dilakukan untuk mendapatkan jawaban. Mulai dari bertanya pada teman, bahkan saling tukar lembar jawaban, hingga melihat catatan kecil di kertas atau di handphone yang telah dipersiapkan sebelumnya 
(Friyatmi, 2011) Menyontek saat sekarang ini sudah menyentuh dari sekolah dasar hingga perguruan tinggi.

Perilaku menyontek yang terjadi di perguruan tinggi terjadi karena adanya anggapan bahwa menyontek merupakan hal yang biasa dan lazim untuk dilakukan. Tindakan seseorang untuk menyontek ini didorong oleh adanya pandangan bahwa tindakan itu memiliki keuntungan bagi dirinya dan adanya keyakinan bahwa orang lain ingin dia melakukannya. (Amalia, 2016) padahal adanya tindakan-tindakan menyontek didalam proses pendidikan akan sangat berpengaruh terhadap lulusan yang dihasilkan nantinya. Hasil penelitian James (2013) menunjukan bahwa Ketidakjujuran didalam proses pendidikan akan dapat membahayakan masa depan mahasiswa sebagai anggota masyarakat yang produktif nantinya.

Menyontek merupakan bentuk kriminalitas yang ada di institusi pendidikan yang selama ini kita biarkan. Sehingga menjadi suatu kebiasaan yang merupakan bentuk krisis moral bangsa kita pada saat sekarang ini. Dan jika dibiarkan nantinya tentu akan bisa menciptakan calon-calon pemimpin masa depan yang bertindak curang. Berdasarkan fenomena diatas maka artikel ini akan membahas tentang menyontek sebagai bentuk krisis moral bangsa.

\section{B. TEORI}

\section{Menyontek}

Menyontek adalah perilaku yang tidak terpuji atau perbuatan curang yang dilakukan oleh seseorang yang dilakukan dengan cara menjiplak, meniru, mencontoh ataupun mengambil hasil pekerjaan orang lain baik dengan izin atau tidak disertai izinnya ataupun membuat catatan khusus yang telah dibuat sendiri sebelum menghadapi ujian untuk mencapai keberhasilan dalam hal akademik yang terkait dengan evaluasi/ujian hasil belajar. (Samiroh, 2015)

Menurut Hartanto (2012) menyontek adalah kegiatan menggunakan bahan yang tidak diperkenankan atau menggunakan pendampingan secara terlarang, baik dalam pengerjaan tugas-tugas akademik, tes, dan/atau kegiatan lain yang dapat mempengaruhi proses penilaian. Sehingga, dapat dikatakan bahwa intensi menyontek adalah suatu kecenderungan atau keyakinan seseorang untuk melakukan perbuatan curang dan terlarang secara sengaja untuk menghindari kegagalan atau mendapatkan keuntungan secara tidak adil dalam bidang akademik. Menyontek adalah perbuatan yang menggunakan cara-cara yang tidak sah untuk tujuan yang sah dan terhormat yaitu mendapatkan keberhasilan akademik untuk menghindari kegagalan akademik. (Purnamasari, 2013)

Menyontek merupakan perilaku yang dapat terjadi karena adanya pengaruh baik dari dalam diri maupun karena interaksi dengan dunia luar. 
Sebagai sebuah bentuk perilaku, menyontek merupakan hasil bentukan akibat pengamatan atau hasil interaksi dengan lingkungan. Sehingga demikian perilaku menyontek antara individu satu dengan yang lain dapat berbeda-beda tergantung bagaimana pengaruh yang disebabkan faktor dari luar. Perilaku menyontek diharapkan dapat dirubah atau dihentikan kembali dengan cara yang benar. (Warsiyah, 2013)

\section{Dekadensi Moral}

Kata dekadensi berasal dari bahasa Inggris yaitu "Decadence" yang artinya kemunduran, kehancuran. Dekadensi secara etimologis berarti kemunduran, kemerosotan tentang kebudayaan. Dekadensi moral remaja sering dipakai istilah kenakalan remaja yaitu suatu kelainan tingkah laku, perbuatan atau tindakan remaja yang bersifat a-sosial, bahkan anti sosial yang melanggar norma sosial, agama serta ketentuan yang berlaku dalam masyarakat. Pengertian Dekadensi Moral Adalah kemunduran atau kemrosotan yang dititikberatkan pada perilaku atau tingkah laku, kepribadian dan sifat. Dalam istilah lain, bahwa dekadensi moral adalah sebuah bentuk kemerosotan atau kemunduran dari kepribadian, sikap, etika dan akhlak seseorang. (Daradjat, 2000)

Santrock (2008) menuturkan bahwa perkembangan moral adalah berhubungan dengan peraturan-peraturan dan nilai-nilai mengenai apa yang harus dilakukan seseorang dalam interaksinya dengan orang lain. perkembangan moral dalam pandangan pembelajaran sosial kognitif memberikan penekanan pada adanya perbedaan antara kompetensi moral remaja (kemampuan untuk melakukan tingkah laku moral) dan performa moral remaja (tingkah laku yang dimunculkan pada situasi yang spesifik.

\section{PEMBAHASAN}

Sistem pendidikan di negara kita pada saat sekarang ini belum memberi ruang yang luas kepada peserta didik untuk bisa mengembangkan diri dan pikirannya secara mandiri. Peserta didik hanya dijadikan sebagai objek pembelajaran, hanya sekadar kegiatan teknis yang mengajarkan pengertianpengertian atau hanya sebagatas transfer knowladge. Pikiran murid seolah-olah sekadar menjadi bank data informasi saja. Padahal seharusnya sistem pendidikan harus menjadi tempat perubahan perilaku manusia dari yang tidak baik menjadi baik, tapi karena sistem pendidikan juga dijadikan sebagai alat untuk legalitas kekuasaan. Sehingga dalam praktiknya, pendidikan di negara kita tidak sesuai dengan harapan. Adanya Ujian Nasional hannya pada bidangbidang studi tertentu yang hanya memberi stimulus pada otak kanan. Padahal pendidikan sebenarnya bertujuan untuk memanusiakan manusia. (Bakri, 2009) 
Menyontek sebagai salah satu bentuk dekadensi moral bangsa yang tentunya akan dapat menyebabkan pembiasaan perilaku yang tidak baik. Berdasarkan hasil penelitian yang dilakukan kepada 106 orang mahasiswa di Perguruan Tinggi Kesehatan di Kota Padang didapatkan 45,3 \% responden berprilaku kurang baik terhadap perilaku menyontek. Untuk jelasnya dapat dilihat berdasarkan tabel distribusi frekuensi sebagai berikut:

Tabel 1 Distribusi Frekuensi Perilaku Menyontek di Sekolah Tinggi Kesehatan (STIKES)

\begin{tabular}{lcc}
\hline Perilaku Menyontek & f & \% \\
\hline Kurang Baik & 48 & 45,3 \\
Baik & 58 & 54,7 \\
Total & $\mathbf{1 0 6}$ & $\mathbf{1 0 0}$ \\
\hline
\end{tabular}

Berdasarkan tabel 1 terlihat bahwa dari 106 responden terdapat 48 $(45,3 \%)$ responden beprilaku kurang baik dan sebanyak 58 (54,7\%) responden berprilaku baik dalam perilaku menyontek pada mahasiswa STIKES. Berdasarkan data ini kita dapat melihat bahwa sebagian mahasiswa di STIKES memiliki perilaku kurang baik didalam menyontek, dimana berdasarkan hasil penelitian terlihat bahwa hampir separuh siswa membawa contekan pada saat ujian. Hal ini sebagai salah satu bentuk bagaimana mereka melakukan persiapan untuk akan menyontek pada saat ujian.

Melihat dari hasil tersebut kita dapat memberikan gambaran bahwa bagaimana bentuk kecurangan yang ada di dunia pendidikan kita saat sekarang ini. Hal ini merupakan salah satu dekadensi moral bangsa yang ada di negara kita, yang disebabkan oleh sistem penilaian pendidikan kita yang menjadikan hasil akhir pembelajaran berdasarkan data kuantitatif yang didapatkan dari tes yang hanya menguji kemampuan pengetahuan siswa dan tanpa melihat sebagaimana siswa itu paham tentang pembelajaran yang diajarakan.

Dekadensi moral yang merupakan bentuk kemerosotan moral yang dialami oleh bangsa. Menyontek sebagai salah satu bentuk kemerosotan moral tersebut. Indonesia berideologikan Pancasila, yang berarti percaya dengan adanya Tuhan. Namun menyontek merupakan suatu perilaku tidak baik atau suatu perilaku curang dalam dunia pendidikan. hal ini tentunya tidak sesuai dengan sila Ketuhan tersebut. Jika hal ini terus dibiarkan, tentu akan memberikan dampak negatif terhadap perkembangan moral generasi muda Indonesia untuk kedepannya.

Melihat fenomena tersebut sangat kita sayangkan sekali dimana kredibilitas dan kewibaawan dunia pendidikan. para peserta didik yang seharusnya menunjukan sikap dan perbuatan yang bermuatan akhlak mulia justru menunjukan sikap dan perilaku yang curang dan tidak jujur. Hal ini 
disebabkan oleh kurangnya fungsi pendidikan sebagai transfer nilai (transformation of value) dan hanya berlaku transfer pengetahuan (transformation of knowledge).

\section{PENUTUP}

Menyontek merupakan tindakan yang lazim dilakukan oleh pelajar dan mahasiswa. Tindakan menyontek yang dilakukan pada saat proses pendidikan nantinya akan dapat berpengaruh terhadap kinerja lulusan. Lulusan yang terbiasa menyontek pada saat perkuliahan akan memberikan dampak buruk pada saat pelaksanaan pekerjaannya. Jika dekadensi moral ini terus kita biarkan maka akan berdampak terhadap keberlangsungan negara kita untuk kedepannya. Peserta didik yang sekarang ini berprilaku menyontek tentunya nanti akan menjadi pemimpin masa depan yang akan juga menggunakan tindakan-tindakan kecurangan dalam bertindak kedepannya.

\section{E. DAFTAR PUSTAKA}

Albrecht, W. Steve. 2012. Fraud Examination (Fourth Edition). South-Western: USA.

Amalia, Nadhiratul. 2016. Hubungan Goal Orientation Dan Motivasi Berprestasi Dengan Intensi Menyontek Pada Mahasiswa Program Studi Psikologi Universitas Mulawarman. Ejournal Psikologi, 2016. 4(3): 294-305

Anderman, E. M., \& Murdock, T. B., (eds). (2007). Psychology of Academic Cheating. New York: Academic Press Inc.

Anderman, E. M., Cupp, P. K., \& Lane, D. (2010). Impulsivity and Academic Cheating. The Journal of Experimental Education. 78, p. 135-150

Angelia, Inge. 2016. Study kualitatif tentang Budaya Menyontek pada Siswa SMP. Laporan Penelitian. Stikes Syedza Saintika Padang.

Bakri, Syamsul. 2009. Agama, Persoalan Sosial dan Krisis Moral. Jurnal Dakwah dan Komunikasi . Vol 3. No. 1.

Błachnio, Agata and Malgorzata Weremko. 2011. Academic Cheating is Contagious: the Influence of the Presence of Others on Honesty. a Study Report. International Journal of Applied Psychology. 2011; 1(1): 14-19

Daradjat, Zakiyah.2000. Ilmu Pendidikan Islam. Jakarta: Bumi Aksara. 
Friyatmi, 2011, Faktor-faktor Penentu Perilaku Mencontek di Kalangan Mahasiswa, Fakultas Ekonomi UNP Vol 7, No 2 (2011)

Hartanto, Dody. 2012. Mengatasi Masalah Menyontek. Yogyakarta: Indeks Jakarta.

James Moten Jr., Alex Fitterer, Elise Brazier, Jonathan Leonard and Avis Brown. 2013. Examining Online College Cyber Cheating Methods and Prevention Measures. Electronic Journal of e-Learning Volume 11 Issue 2 2013

Nurmayasari, Kiki dan Hadjam Murusdi. 2015. Hubungan Antara Berpikir Positif Dan Perilaku Menyontek Pada Siswa Kelas X SMK Koperasi Yogyakarta. Jurnal Fakultas Psikologi. Vol. 3, No 1, Juli 2015

Nursalam, 2015. Metodologi Penelitian ilmu Keperawatan. Jakarta:EGC.

Pujiatni, Kris dan Sri Lestari. 2010. Studi Kualitatif Pengalaman Menyontek Pada Mahasiswa. Jurnal Penelitian Humaniora, Vol. 11. 2. 2010. Hal-103110

Purnamasari, D. (2013). Faktor-faktor yang mempengaruhi kecurangan akademik pada mahasiswa. Educational Psychology Journal. 2 (1) 13 - 21.

Samiroh dan Zidni Immawan Muslimin. 2015. Hubungan Antara Konsep Diri Akademik Dan Perilaku Menyontek Pada Siswa- Siswi Mas Simbangkulon Buaran Pekalongan. PSIKIS-Jurnal Psikologi Islami Vol. 1 No. 2 (2015) 67-77

Sanjaya, Wina. 2013. Perencanaan E Desain Sistem Pembelajaran. Jakarta: Kencana Prenada Media Group.

Santrock, J.W., 2008, Psikologi Pendidikan, Alih Bahasa Tri Wibowo B.S., Jakarta: Kencana

Warsiyah. 2013. Perilaku Menyontek Mahasiswa Muslim. Tesis. Institusi Agama Islam Negeri (IAIN) Walisongo.

Wideman, Maureen A. 2008. Academic Dishonesty in Postsecondary Education: A literature review. Transformative Dialogues: Teaching $\mathcal{E}$ Learning Journal. Volume 2, Issue 1. Hal 1-12

Yulianto, Heri. 2015. Persepsi Mahasiswa Tentang Ketidak-jujuran Akademik: Studi Mahasiswa Program Vokasi Universitas Indonesia. Seminar Psikologi dan kemanusian. 